\title{
The Effect of The Specific Phosphodiesterase Type V Inhibitor, "Sildenafil Citrate", on Alloxan-Induced Diabetic Rabbit Corpus Cavernosal Smooth Muscle
}

\author{
Safwat.E. Abou Hashem*; Kariman El-Houssieni Sleim**; Soad \\ Abdalla Sleim **;Hesham El-Gendy*and Ahmed A. Abd-El-Aal ${ }^{*}$ \\ * Department of Urology and **Department of Physiology, Faculty of \\ Medicine, Zagazig University
}

\begin{abstract}
This study was carried out to investigate the effect of sildenafil (S) together with the influence of sodium nitroprusside (SNP) and acetylcholine (Ach) on isolated strips of rabbit corpus cavernosum. The in vitro effects of sildenafil on non-adrenergic, noncholinergic and nitric oxide (NO)-mediated cavernosal smooth muscle relaxation in diabetic rabbits, were also investigated. Diabetes mellitus was induced in adult male New Zealand white rabbits with alloxan $(65 \mathrm{mg} / \mathrm{kg}$, i.v). Cavernosal strips from agematched control and 5 months diabetic animals were mounted in organ baths containing Krebs-bicarbonate solution ( $\mathrm{pH} 7.4$, bubbled continueously with a gas mixture of $95 \%$ $\mathrm{O}_{2}$ plus $5 \% \quad \mathrm{CO}_{2}$, and maintained at $37^{\circ} \mathrm{C}$. Isolated strips of control rabbit corpus cavernosum were stimulated isotonically with phenylephrine $\left(10^{-5} \mathrm{M}\right)$ and relaxations were induced using increasing concentrations of Ach, SNP and S alone and in combination. Also, relaxation responses of control and diabetic strips precontracted with phenylephrine $\left(10^{-5} \mathrm{M}\right)$ to electrical field stimulation (EFS, 4-20 Hz) or SNP $\left(10^{-9}-\right.$ $10^{-3} \mathrm{M}$ ) were assessed in the absence and presence of a submaximal dose of sildenafil $\left(10^{-6} \mathrm{M}\right)$.

It was found that Ach, SNP and S relaxed the control rabbit corpus cavernosal strips in a dose-dependent manner. The relaxant effect of the test agents were ranked (from least inhibitory to most inhibitory) as follows: S, Ach plus S, SNP, SNP plus S, Ach. Moreover, it was observed that SNP-stimulated relaxations were significantly impaired in the corpus cavernosum from diabetic group compared to age-matched controls. Sildenafil $\left(10^{-6} \mathrm{M}\right)$ significantly enhanced SNP-stimulated relaxation in control and diabetic groups. Electrical field stimulation-mediated relaxations of the corpus cavernosum were significantly impaired after 5 months diabetes mellitus and enhanced by sildenafil $\left(10^{-6} \mathrm{M}\right)$.

In conclusion, sildenafil enhances the relaxing effect of both SNP and Ach on the phenylephrine-induced contraction of rabbit cavernosal tissue. It could also be suggested that the impairment of NO-mediated relaxation of the diabetic corpus cavernosum reflect, at least in part, a defect in guanyl cyclase activity. These findings support the use of sildenafil as an effective, orally administered, treatment for diabetic erectile dysfunction.
\end{abstract}




\section{Introduction and Aim of the Work}

Many studies have highlighted the pivotal role of nitric oxide (NO) and its stimulation of cyclic guanosine monop hosphate (cGMP) in the mediation of the penile corpus cavernosal smooth muscle relaxation and erection (Kim et al., 1991; De Tejada, 1992; TrigoRocha et al., 1993; Finberg et al., 1993; Burnet, 1995).

NO is synthesized in the nerve terminals of the parasympathetic nonadrenergic, noncholinergic neurons in the penis corpus cavernosum and also by the endothelial cells lining the blood vessels (arteries that supply the penis) and the lacunar space of the corpora cavernosa (Burnet et al., 1992; TrigoRocha et al., 1993; Bredt and Snyder, 1994). It activates guanylate cyclase, resulting in an increased conversion of guanosine triphosphate to cGMP. cGMP is an important intracellular messenger for transducing extracellular signals in corpus cavernosal smooth muscle cells (Burnet, 1995; Holmquist et al., 1991). By binding to cGMPdependent protein kinases and to cGMP-dependent ion channels, it reduces intracellular calcium levels (Meyer et al., 1993). Reduced intracellular calcium levels result in trabecular smooth muscle relaxation, enabling corporal volume expansion (Moreland et al., 1998; Carter et al., 1998). The level of cGMP is regulated by a balance between the rate of synthesis and the rate of hydrolytic breakdown to cGMP by cyclic nucleotide phosphodiesterase (PDE) isoenzymes (Beavo, 1992). Therefore agents that inhibit cGMP hydrolysis may increase the cGMP signal and could be expected to enhance the relaxation of the smooth muscle in the corpus cavernosum and thereby facilitate penile erectile responses (Ballard et al., 1998).
It is now widely accepted that the risk factors that underlie the development of vascular disease are identical to those that predispose to vasculogenic erectile dysfunction (Virag et al., 1984; Krane et al., 1989; Azadzoi and DeTejada, 1991, 1992; Shabsigh et al., 1991; Azadzoi and Goldstein, 1992; Lerner et al., 1993). A major risk factor for both atherogenesis and erectile dysfunction is diabetes mellitus (De Tejada et al., 1989; Blanco et al., 1990). The prevalence of erectile dysfunction in diabetic men is high (Krane et al., 1989; Blanco et al., 1990; Lerner et al., 1993).

Nonadrenergic noncholinergic (NANC) drive is adversely affected by diabetes mellitus (De Tejada et al., 1989) with subsequent impairment of corpus cavernosal relaxation. This may be due to, at least in part, to the development of diabetic neuropathy, which has been shown to contribute to neurogenic erectile dysfunction (Krane et al., 1989; Blanco et al, 1990; Lerner et al., 1993).

Previously, the pharmacological treatment of erectile dysfunction has been confined to intracovernosal (Virag, 1982; Von Heyden et al., 1993; Shenfeld et al., 1995) and transuretheral (Padma-Nathan et al., 1997) injections of drugs such as papaverine and prostaglandine $\mathrm{E}_{1}$.

Sildenafil is a selective phosphod iesterase type 5 inhibitor, which is widely used for the oral treatment of erectile dysfunction, regardless of etiology. It enhances NO-mediated cGMP - formation / accum -ulation resulting in a significant relaxation of the corpus cavernosum (Ballard et al., 1996; Jeremy et al., 1997). It effectively blocks phosphodiesterase type 5mediated hydrolysis of cGMP. Data obtained from rabbit corpus cavernosal 
tissues have demonstrated that sildenafil increases endogenous corpus cavernosal smooth muscle cGMP and induces relaxation of the muscles (Jeremy et al., 1997; Chuang et al., 1988). It has also been suggested that the sildenafilinduced enhancement of cGMP accum ulation is dependent on a priori endog enous NANC and parasymp -athetic drive (Jeremy et al., 1997).

Therefore, the objectives of this study was to (1) examine the effects of sildenafil in the physiologically impor tant NO-cGMP signal transduction pathway for relaxation of corpus caver nosal smooth muscle and to compare it with endothelial-dependent relaxation of acetylcholine and endothelialindependent relaxation of sodium nitroprusside. (2) test the possible effect of sildenafil on relaxa -tion of the corpus cavernosum of the diabetic rabbits and age-matched controls.

\section{Material \& Methods}

\section{Induction of diabetes mellitus:}

Adult male white rabbits $(n=6)$ were made diabetic by injection of alloxan (Sigma Chemical Co., Pool, UK), $65 \mathrm{mg} / \mathrm{kg}$ body weight in a single dose into lateral ear vein while they were under anaesthesia (45 $\mathrm{mg} / \mathrm{kg}$ sodium pentobarbital). All animals were fed adlibitum and standard rabbit plain diet and allowed free access to water.

Induction of diabetes was ascert ained by determination of blood glucose concentration in blood obtained from ear artery $72 \mathrm{~h}$ and weekly after alloxan injection and confirmed by a blood glucose level) $300 \mathrm{mg} / \mathrm{dL}$ associated with marked reduction in serum insulin level at death.

\section{Measurement of blood glucose conce - ntration and serum insulin level:}

Blood glucose was measured by using Reflolux II reflactance photo meter (Boehring Mannheium, Germany) and serum insulin level was determined by Enzyme linked immunosorbant Assay (ELISA) method using specific kits (Bioscience, Europe, SA).

\section{Organ bath studies:}

The samples of corpus cavernosal tissue used to study the functional effects of sildenafil were obtained from 5 months diabetic sexually mature male rabbits $(n=6)$ and age matched control rabbits $(n=6)$. Under intraperitoneal thiopental anesthesia, penectomies were performed on the animals, with isolation of 2-3 smooth muscle strips (approximately $1 \times 3 \mathrm{~mm}$ ) from the enveloping tunica albuginea of each animal which was then killed by cervical decapitation, the size and weights of the tissues from both control and diabetic rabbits were similar. Freshly dissected cavernosal strips were tied at each end with surgical silk threads and mounted in $10 \mathrm{ml}$ capacity water-Jacked tissue bath chambers containing Kreb's-bicarbonate solution (6.9gm NaCl, $2.1 \mathrm{gm} \mathrm{NaHCO}_{3}, 0.34 \mathrm{gm}$ $\mathrm{KCl}, 0.16$ gm $\mathrm{KH}_{2} \mathrm{PO}_{4}, 0.3$ gm $\mathrm{MgSO}_{4}$, $2.00 \mathrm{gm}$ D.glucose, and $0.18 \mathrm{gm} \mathrm{CaCl}_{2}$ in $1 \mathrm{~L}$ distilled water) of $\mathrm{pH} 7.4$, maintained at $37^{\circ} \mathrm{C}$ by thermoregulated circuit and bubbled continuously with $95 \%$ oxygen and $5 \%$ carbon dioxide.

The upper end of each strip was connected to a lever writing on the rotating drum of the universal kymo graph (Bioscience, Washington). The initial resting tension of each strip was set at $2 \mathrm{gm}$, and the tissues were allowed to equilibrate for 60 minutes. The tissue samples were then washed with Krebs solution with a high $(120 \mathrm{nM}) \mathrm{K}^{+}$conc entration (Krebs-KCl solution) (0.22 gm $\mathrm{NaCl}, 2.10$ gm $\mathrm{NaHCO}_{3}, 8.86$ gm KCl, 0.16 gm KH $2 \mathrm{PO}_{4}, 0.30$ gm $\mathrm{MgSO}_{4}, 1.98$ gm D-glucose and $0.18 \mathrm{gm} \mathrm{CaCl}_{2}$ in IL distilled water) for 15 minutes to depolarize the tissue and induce a contractile response. After this step, the 
tissues were allowed to return to the baseline tension by repeatedly washing them for 30 minutes with Krebs solution. the organ baths were refilled with $10 \mathrm{ml}$ Krebs solution, and then the tissue strips were contracted with phenylephrine hydrochloride at increa sing concentrations $\left(10^{-9}-10^{-3} \mathrm{M}\right)$ to obtain a dose response curve for the contractile effect of phenylephrine and to find out the submaximal contractile concentration of phenylephrine. In other studies, tissues were:

a) Precontracted with the submaximal dose of phenylephrine $\left(10^{-5} \mathrm{M}\right)$ and dose response curves were constru cted for the relaxant effect of SNP $\left(10^{-9}-10^{-3} \mathrm{M}\right)$, Ach $\left(10^{-9}-10^{-3} \mathrm{M}\right)$ and sildenafil $\left(10^{-9}-10^{-3} \mathrm{M}\right)$.

b) Precontracted with phenylephrine $\left(10^{-5} \mathrm{M}\right)$ and dose response curves were constructed for the relaxant effect of sildenafil $\left(10^{-9}-10^{-3} \mathrm{M}\right)$ in the presence of the minimal conce ntration of either SNP $\left(10^{-8} \mathrm{M}\right)$ or Ach $\left(10^{-9} \mathrm{M}\right)$ that induced a signif icant relaxant effect in order to demonstrate any synergistic or additive effects of sildenafil.

c) Precontracted with phenylephrine $\left(10^{-5} \mathrm{M}\right)$, a submaximal dose of sild enafil $\left(10^{-6} \mathrm{M}\right)$ was then added to the organ bath and after $15 \mathrm{~min}$, dose response curves were again constr ucted for SNP.

d) Bathed with krebs solution which also contained guanithidine $\left(5 \times 10^{-}\right.$ $\left.{ }^{6} \mathrm{M}\right)$, atropine $\left(10^{-5} \mathrm{M}\right)$ and indome thacine $\left(10^{-6} \mathrm{M}\right)$ to inhibit the adrenergic, cholinergic and cycloo xygenase pathways, respectively leaving the NANC pathway intact. The strip were then, precontracted with phenylephrine $\left(10^{-5} \mathrm{M}\right)$ and stimulated at frequencies of $4,8,12$, 16 and $20 \mathrm{~Hz}$, with a stimulator delivering single square waves (duration $0.8 \mathrm{sec}$ ) in absence and presence of sildenafil $\left(10^{-6} \mathrm{M}\right)$ which was added to the organ bath 15 minutes before electric field stimulations (EFS). These experim ents were used to demonstrate the effect of sildenafil on NANCmediated relaxation of corpus cavernosal strips taken from 5 months diabetic and age matched control rabbits.

\section{Drugs \& Chemicals:}

Ach, phenhylephrine, SNP, alloxan, guanithidine, atropine, and indomethacine were purchased from Sigma Chemical Co. (UK) while sildenafil citrate was obtained from Pfizer Chemical Co. (Egypt).

Statistical analysis:

All data were expressed as mean \pm S.E and statistically analysed according to ANOVA test and student's unpaired to test. A $\mathrm{P}$ value $<0.05$ was considered statistically significant.

\section{Results}

Table (1) illustrates the effects of alloxan-induced diabetes in adult male rabbits. Induction of diabetes signific antly increased blood glucose level from $7.02 \pm 0.19 \mathrm{mmol} / \mathrm{L}$ in normal control group to $22.5 \pm 1.78 \mathrm{mmol} / \mathrm{L}$ in the diabetic group $(\mathrm{P}<0.001)$, and reduced blood insulin level from $82.66 \pm 2.4 \mathrm{pmol} / \mathrm{L}$ in the control group to reach $27.5 \pm 1.74 \mathrm{pmol} / \mathrm{L}$ in the diabetic group $(\mathrm{P}<0.001)$. Diabetic rabbits also gained significantly less body weight $(3.3 \pm 0.18 \mathrm{~kg})$ when comp ared to both their initial body weight $[(3.15 \pm 0.19 \mathrm{~kg}), \mathrm{P}>0.05]$ and the final body weight of normal control group $[(4.05 \pm 0.14 \mathrm{~kg}), \mathrm{P}<0.01)$.

Table (2), Fig. (1) demonstrate the relaxant effect of sildenafil (in absence and presence of either ACh $\left(10^{-9} \mathrm{M} / \mathrm{L}\right)$ or SNP $\left(10^{-8} \mathrm{M} / \mathrm{L}\right)$, Ach and SNP on phenylephrine $\left(10^{-5} \mathrm{M}\right)$-induced contra - 
ction in rabbit corpus cavernosal tissue strips. It was found that the inhibitory effect of test agents were ranked (from least inhibitory to most inhibitory) as follows: sildenafil, acetylcholine plus sildenafil, sodium nitroprusside, sodium nitroprusside plus sildenafil, acetylc holine. Sildenafil was observed to have little effect on the phenylephrineinduced contraction even at the highest concentration tested. However, its effect was potentiated in the presence of acetylcholine and SNP.

Table (3) \& Fig (2) show the effect of sildenafil on SNP-mediated relaxation of corpus cavernosal strips taken from 5 months diabetic and agematched control rabbits. The strips were precontracted with phenylephrine $\left(10^{-}\right.$ $\left.{ }^{5} \mathrm{M}\right)$ in absence and presence of silde nafil $\left(10^{-6} \mathrm{M}\right)$ which was added $15 \mathrm{~min}$ before the addition of SNP. Results were expressed as \% of relaxation $(\mathrm{X} \pm$ S.E $)$ of the phenylephrine-induced tone.

It was found that SNP-mediated relaxation of 5 months-diabetic corpus cavernosal strips were significantly impaired when compared to agematched control strips $(\mathrm{P}<0.001$; ANOVA test). A significant difference in SNP-mediated relaxation between age-matched controls and 5 months diabetic cavernosal strips at each data point using student's unpaired t-test, was also observed. On the other hand, it was noticed that sildenafil significantly enhanced the SNP-mediated corpus cavernosal relaxation in both diabetic and age matched control strips $(\mathrm{P}<$ 0.001; ANOVA test respectively). A significant difference in SNP-mediated relaxation between the absence and presence of sildenafil at each data point using student's unpaired t-test was also found.

Table (4) \& Fig. (3) illustrate the effect of sildenafil $\left(10^{-6} \mathrm{M}\right)$ on EFS (NANC)-mediated relaxation of corpus cavernosal strips taken from 5 months diabetic and age-matched control rabbits. The strips were precontracted with phenylephrine $\left(10^{-5} \mathrm{M}\right)$, sildenafil was then added and after $15 \mathrm{~min}$, EFS was at frequencies of 4, 8, 12, 16 and $20 \mathrm{~Hz}$. It was found that, EFS-induced relaxations were significantly impaired when comparing 5 months diabetic to age-matched control strips $(\mathrm{P}<0.001$ ANOVA test). However, sildenafil significantly enhanced the EFSstimulated corpus cavernosal relaxat ions in 5 months diabetic and agematched control rabbits ( $\mathrm{P}<0.001 \&$ $\mathrm{P}<0.001$, respectively; ANOVA test). A significant difference in EFS-stimulated relaxation between the absence and presence of sildenafil, at each data point, in 5 months diabetic and agematched control rabbits using a student's unpaired t-test, was also detected. 
Table (1): The effect of alloxan induced diabetes on blood glucose level, serum insulin concentration and body weight in adult male rabbits.

\begin{tabular}{|l|c|c|c|}
\hline \multicolumn{1}{|c|}{ Parameter } & $\begin{array}{c}\text { Control } \\
\mathbf{N}=\mathbf{6}\end{array}$ & $\begin{array}{c}\text { Diabetic } \\
\mathbf{N = 6}\end{array}$ & P \\
\hline $\begin{array}{l}\text { Blood glucose } \\
(\mathbf{m m o l} / \mathbf{L})\end{array}$ & $7.02 \pm 0.19$ & $22.5 \pm 1.78$ & $<0.001$ \\
\hline $\begin{array}{l}\text { Blood insulin } \\
(\mathbf{p m o l} / \mathbf{L})\end{array}$ & $82.66 \pm 2.4$ & $27.5 \pm 1.74$ & $<0.001$ \\
\hline $\bar{X} \pm$ SE & $3.0 \pm 0.15$ & $3.15 \pm 0.19$ & $>0.05$ \\
\hline $\begin{array}{l}\text { Initial body } \\
\text { weight } \\
(\text { Kg) }\end{array}$ & & & \\
$\bar{X} \pm$ SE & $4.05 \pm 0.14$ & $3.3 \pm 0.18$ & $<0.01$ \\
\hline $\begin{array}{l}\text { Final body weight } \\
(\text { Kg) }\end{array}$ & $\bar{X} \pm$ SE & & \\
\hline
\end{tabular}

Table (2): The effect of SNP, Ach and S [in the presence and absence of either Ach $\left(10^{-}\right.$ $\left.{ }^{9} \mathrm{M}\right)$ or $\left.\mathrm{SNP}\left(10^{-8} \mathrm{M}\right)\right]$ on corpus cavernosal strips taken from control rabbits. The strips were precontracted with phenylephrine $\left(10^{-5} \mathrm{M}\right)$.

\begin{tabular}{|c|c|c|c|c|c|c|}
\hline $\begin{array}{l}\text { DOSES } \\
\text { (Mol/L) }\end{array}$ & $\begin{array}{c}S \\
N=6\end{array}$ & $\begin{array}{c}\mathrm{Ach}+\mathrm{S} \\
\mathrm{N}=6\end{array}$ & $\begin{array}{l}\mathrm{SNP} \\
\mathrm{N}=6\end{array}$ & $\begin{array}{c}\mathrm{SNP}+\mathrm{S} \\
\mathrm{N}=6\end{array}$ & $\begin{array}{l}\text { Ach } \\
N=6\end{array}$ & $\mathbf{F}$ \\
\hline$\frac{10^{-9}}{X} \pm \mathrm{SE}$ & 0 & $6.66 \pm 2.4$ & $8.88 \pm 1.4$ & $11.1 \pm 1.4$ & $19.9 \pm 1.7$ & $20.575^{* * *}$ \\
\hline $\begin{array}{l}10^{-8} \\
X \pm \mathrm{SE}\end{array}$ & 0 & $12.2 \pm 0.99$ & $15.6 \pm 1.4$ & $28.8 \pm 2.8$ & $35.6 \pm 2.2$ & $51.841^{* *}$ \\
\hline$\frac{\overline{10}^{-7}}{X} \pm \mathrm{SE}$ & $3.33 \pm 1.5$ & $21.1 \pm 3.2$ & $32.2 \pm 2.7$ & $46.7 \pm 1.7$ & $63.3 \pm 2.9$ & $86.903^{* *}$ \\
\hline$\frac{10}{X}_{ \pm \mathrm{SE}}^{-6}$ & $8.9 \pm 2.2$ & $27.8 \pm 3.2$ & $43.33 \pm 1.5$ & $63.3 \pm 2.9$ & $81.1 \pm 4.00$ & $97.755^{* *}$ \\
\hline$\overline{10}^{-5}{ }_{ \pm \mathrm{SE}}$ & $17.7 \pm 1.4$ & $36.7 \pm 2.85$ & $59.99 \pm 3.4$ & $72.2 \pm 3.2$ & $92.2 \pm 2.04$ & $117.943^{* *}$ \\
\hline $\begin{array}{l}\overline{10}^{-4} \\
X \pm \mathrm{SE}\end{array}$ & $23.3 \pm 2.3$ & $53.33 \pm 2.4$ & $73.33 \pm 3.8$ & $84.4 \pm 2.2$ & $99.9 \pm 2.4$ & $123.710^{* * *}$ \\
\hline$\overline{10}^{-3} \pm \mathrm{SE}$ & $23.3 \pm 2.3$ & $53.33 \pm 2.4$ & $73.33 \pm 3.8$ & $84.4 \pm 2.2$ & $99.9 \pm 2.4$ & $123.710^{* *}$ \\
\hline
\end{tabular}

** $\mathrm{p}<0.001$ 
Table (3):The effect of SNP $\left(10^{-9}-10^{-3} \mathrm{M}\right)$ on phenylephrine $\left(10^{-5} \mathrm{M}\right)$-induced tone of corpus cavernosal strips taken from control and five months diabetic rabbits in the presence of Sildenafil $\left(10^{-6} \mathrm{M}\right)$.

\begin{tabular}{|c|c|c|c|c|c|c|}
\hline \multicolumn{7}{|c|}{$\%$ of relaxation } \\
\hline $\begin{array}{c}\text { SNP } \\
\text { (Mol/L) }\end{array}$ & $\begin{array}{c}\text { Control } \\
N=6\end{array}$ & $\begin{array}{c}\text { Control+S } \\
\mathrm{N}=6\end{array}$ & $\begin{array}{c}\text { Control } \\
\mathrm{N}=6\end{array}$ & $\begin{array}{c}\text { Diabetic } \\
N=6\end{array}$ & $\begin{array}{c}\text { Diabetic }+S \\
N=6\end{array}$ & $\mathbf{F}$ \\
\hline \multirow{2}{*}{$\begin{array}{c}\mathbf{1 0}^{-9} \\
\bar{X} \pm \mathrm{SE} \\
\mathbf{P}\end{array}$} & $8.88 \pm 1.4$ & $18.9 \pm 2.04$ & $8.88 \pm 1.4$ & 0 & $5.6 \pm 2.09$ & \multirow[t]{2}{*}{$23.847^{* *}$} \\
\hline & \multicolumn{2}{|c|}{$<0.01$} & \multicolumn{3}{|c|}{$<0.05$} & \\
\hline \multirow{2}{*}{$\begin{array}{c}1^{-8} \\
\bar{X} \pm \text { SE } \\
\mathbf{P}\end{array}$} & $15.55 \pm 1.4$ & $27.8 \pm 3.18$ & $15.55 \pm 1.4$ & $6.8 \pm 2.49$ & $14.6 \pm 2.03$ & \multirow[t]{2}{*}{$13.407^{* *}$} \\
\hline & \multicolumn{2}{|c|}{$<0.01$} & \multicolumn{3}{|c|}{$<0.05$} & \\
\hline \multirow{2}{*}{$\begin{array}{c}\mathbf{1 0}^{-7} \\
\bar{X} \pm \mathrm{SE} \\
\mathbf{P}\end{array}$} & $32.2 \pm 2.7$ & $44.4 \pm 2.2$ & $32.2 \pm 2.7$ & $15.7 \pm 2.2$ & $28.8 \pm 1.4$ & \multirow[t]{2}{*}{$29.577^{* *}$} \\
\hline & \multicolumn{2}{|c|}{$<0.01$} & \multicolumn{3}{|c|}{$<0.001$} & \\
\hline \multirow{2}{*}{$\begin{array}{c}\mathbf{1 0}^{-6} \\
\bar{X} \pm \mathrm{SE} \\
\mathbf{P}\end{array}$} & $43.33 \pm 1.5$ & $58.9 \pm 2.05$ & $43.33 \pm 1.5$ & $25.6 \pm 3.13$ & $38.9 \pm 2.7$ & \multirow[t]{2}{*}{$32.153^{* *}$} \\
\hline & \multicolumn{2}{|c|}{$<0.001$} & \multicolumn{3}{|c|}{$<0.001$} & \\
\hline \multirow{2}{*}{$\begin{array}{c}\mathbf{1 0}^{-5} \\
\bar{X} \pm \mathrm{SE} \\
\mathbf{P}\end{array}$} & $59.99 \pm 3.4$ & $74.33 \pm 2.1$ & $59.99 \pm 3.4$ & $39.99 \pm 3.4$ & $52.2 \pm 2.1$ & \multirow[t]{2}{*}{$25.789^{* *}$} \\
\hline & \multicolumn{2}{|c|}{$<0.01$} & \multicolumn{3}{|c|}{$<0.01$} & \\
\hline \multirow{2}{*}{$\begin{array}{c}1_{0}^{-4} \\
\bar{X} \pm \text { SE } \\
\mathbf{P}\end{array}$} & $73.33 \pm 3.8$ & $88.8 \pm 2.2$ & $59.99 \pm 3.4$ & $54.4 \pm 2.04$ & $69.99 \pm 3.8$ & \multirow[t]{2}{*}{$20.994^{* *}$} \\
\hline & \multicolumn{2}{|c|}{$<0.01$} & \multicolumn{3}{|c|}{$<0.01$} & \\
\hline \multirow{2}{*}{$\begin{array}{c}\mathbf{1 0}^{-3} \\
\bar{X} \pm \mathrm{SE} \\
\mathbf{P}\end{array}$} & $73.33 \pm 3.8$ & $88.8 \pm 2.2$ & $59.99 \pm 3.4$ & $54.4 \pm 2.04$ & $69.99 \pm 3.8$ & \multirow{2}{*}{$20.994^{* *}$} \\
\hline & \multicolumn{2}{|c|}{$<0.01$} & \multicolumn{3}{|c|}{$<0.01$} & \\
\hline
\end{tabular}

${ }^{* *} \mathrm{p}<0.001$ 
Table (4):The relaxant effect of electrical field stimulation on corpus cavernosal strips taken from control and five months diabetic rabbits in the presence and absence of sildenafil $\left(10^{-6} \mathrm{M}\right)$. The strips were precontracted with phenylephrine $\left(10^{-5} \mathrm{M}\right)$.

\begin{tabular}{|c|c|c|c|c|c|c|}
\hline \multicolumn{7}{|c|}{$\%$ of relaxation } \\
\hline EFS & $\begin{array}{c}\text { Control } \\
\mathrm{N}=6\end{array}$ & $\begin{array}{c}\text { Control+S } \\
\quad \mathrm{N}=6\end{array}$ & $\begin{array}{c}\text { Control } \\
\mathrm{N}=6\end{array}$ & $\begin{array}{c}\text { Diabetic } \\
N=6\end{array}$ & $\begin{array}{c}\text { Diabetic }+S \\
N=6\end{array}$ & $\mathbf{F}$ \\
\hline \multirow{2}{*}{$\begin{array}{l}\mathbf{4 H z} \\
\bar{X} \pm \mathrm{SE} \\
\mathbf{P}\end{array}$} & $21.87 \pm 2.7$ & $31.25 \pm 2.3$ & $21.87 \pm 2.7$ & $11.37 \pm 1.9$ & $20.8 \pm 2.02$ & \multirow[t]{2}{*}{$13.097^{* *}$} \\
\hline & \multicolumn{2}{|c|}{$<0.05$} & \multicolumn{3}{|c|}{$<0.01$} & \\
\hline \multirow{2}{*}{$\begin{array}{l}\mathbf{8 H z} \\
\bar{X} \pm \mathrm{SE} \\
\mathbf{P}\end{array}$} & $44.7 \pm 3.4$ & $58.33 \pm 2.1$ & $44.7 \pm 3.4$ & $25 \pm 2.28$ & $42.7 \pm 1.9$ & \multirow[t]{2}{*}{$21.993^{* *}$} \\
\hline & \multicolumn{2}{|c|}{$<0.01$} & \multicolumn{3}{|c|}{$<0.001$} & \\
\hline \multirow{2}{*}{$\begin{array}{l}\mathbf{1 2 H z} \\
\bar{X} \pm \mathrm{SE} \\
\mathrm{P}\end{array}$} & $56.3 \pm 3.2$ & $70.8 \pm 3.09$ & $56.3 \pm 3.2$ & $34.37 \pm 2.7$ & $54.16 \pm 3.1$ & \multirow[t]{2}{*}{$24.493^{* *}$} \\
\hline & \multicolumn{2}{|c|}{$<0.01$} & \multicolumn{3}{|c|}{$<0.001$} & \\
\hline \multirow{2}{*}{$\begin{array}{l}\mathbf{1 6 H z} \\
\bar{X} \pm \mathrm{SE} \\
\mathbf{P}\end{array}$} & $73.95 \pm 2.9$ & $87.5 \pm 2.28$ & $73.95 \pm 2.9$ & $52.28 \pm 2.6$ & $70.8 \pm 2.08$ & \multirow[t]{2}{*}{$23.547^{* *}$} \\
\hline & \multicolumn{2}{|c|}{$<0.01$} & \multicolumn{3}{|c|}{$<0.001$} & \\
\hline \multirow{2}{*}{$\begin{array}{l}20 \mathrm{~Hz} \\
\bar{X} \pm \mathrm{SE} \\
\mathbf{P}\end{array}$} & $84.4 \pm 2.7$ & $96.87 \pm 1.4$ & $84.4 \pm 2.7$ & $69.8 \pm 3.02$ & $81.25 \pm 2.3$ & \multirow[t]{2}{*}{$21.168^{* *}$} \\
\hline & \multicolumn{2}{|c|}{$<0.01$} & \multicolumn{3}{|c|}{$<0.01$} & \\
\hline
\end{tabular}

$$
\mathrm{p}<0.001
$$
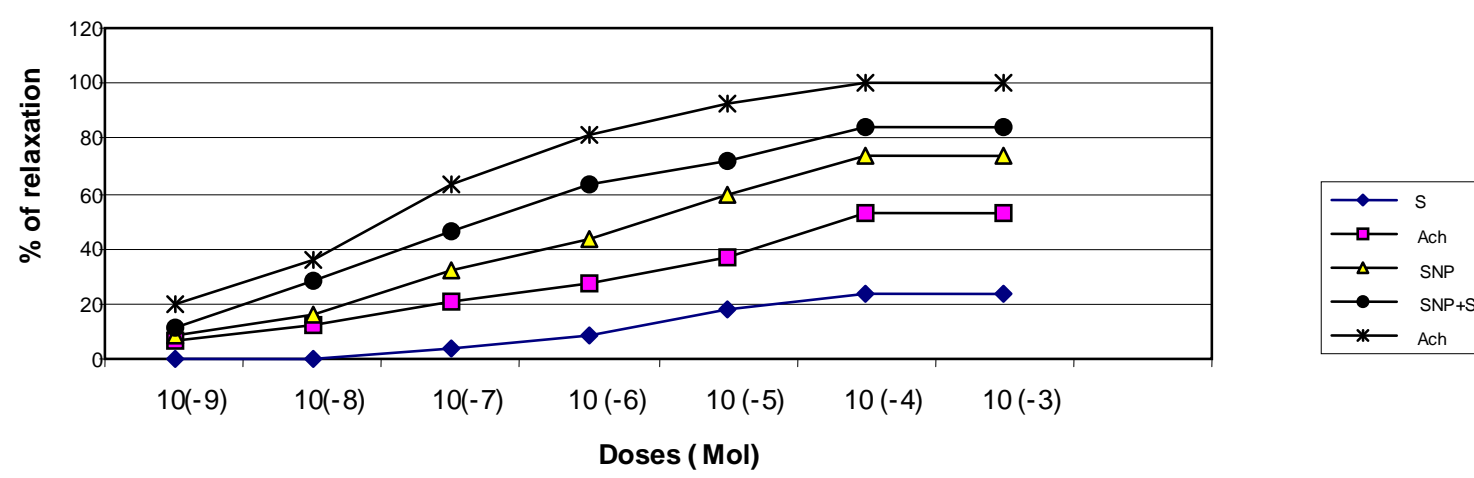

Figur (1): The relaxant effect of SNP,Ach and S[ in the presence and absence of either Ach ( $\left.10^{-9} \mathrm{M}\right)$ or SNP $\left(10^{-8} \mathrm{M}\right)$ ] on corpus cavernosal strips taken from control rabbits.The strips were precontracted with phenylephrine $\left(10^{-5} \mathrm{M}\right)$. 

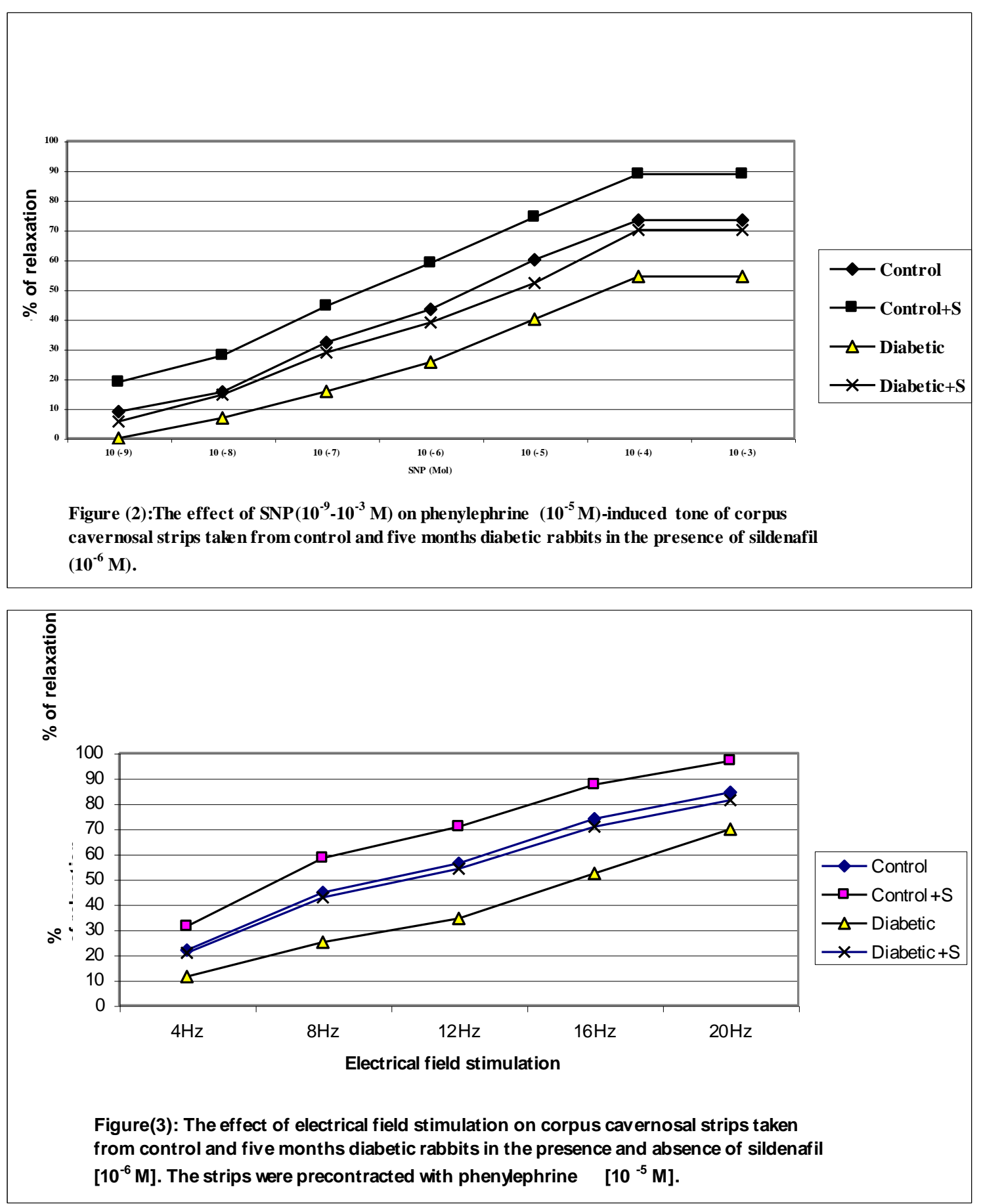

\section{Discussion}

It has been well established that corpus cavernosal smooth muscle relaxation required for erectile function is mainly dependent on the neuronal NO-cGMP system (Burnet, 1995; Carter et al., 1998). Many studies have shown that the potentiating effects of NO synthase inhibitors and NO blockers on erectile mechanisms, both in vitro and in vivo (Trigo-Rocha et al., 1993; 1994 \& Wang et al., 1993).

At present much evidence supports the concept that NO derives from the autonomic innervation of the penis and locally operates as a postganglionic neurotransmitter of non-adrenergic, 
non-cholinergic-mediated penile erecti on. On its synthesis and release from the nerve terminals within the erectile tissue of the penis, NO diffuses into the adjacent smooth muscle cells of the penis. There, it activates the soluble guanylate cyclase present in smooth muscle cells to produce cGMP, which results in smooth muscle relaxation (Ignarro et al., 1990; Bush et al., 1992; Burnett, 1997). Recent research suggests that $\mathrm{NO}$ activates $\mathrm{Na}^{+}-\mathrm{K}^{+}-$ ATPase in human and rabbit corporeal smooth muscle musculature, as well as the potassium conductive membrane hyperpolarization pathway in rabbit corporeal smooth muscle cells (Burnett, 1997).

The present study revealed that slidenafil had little effect on the phenylephrine-induced contraction and this effect was potentiated, at least partially, in the presence of acetylch oline. Sodium nitroprusside (SNP) which breaks down spontaneously in aqueous solution to generate $\mathrm{NO}$ have a more relaxant effect on corpus cavern osal strips precontracted with phenyl ephrine than that of sildenafil alone or sildenafil in the presence of acetylc holine. These results are in agreement with that of Aydin et al. (2001).

The dilatation of vascular beds by choline esters is due to the presence of muscarinic receptors, primarily of $\mathrm{M}_{3}$ subtype, despite the lack of apparent cholinergic innervation of most blood vessels. The muscarinic receptors responsible for relaxation are located on endothelial cells of the vasculature; when these receptors are stimulated, the endothelial cells release the endothelium-derived relaxing factor, or NO, which diffuses to adjacent smooth muscle cells and causes them to relax (Brown and Taylor, 1995). Thus, NO release from NANC neurons is not the only mechanism involved in erection.
This indicates that the principle mode of action of sildenafil is through enhance ment of cAMP accumulation, which is dependent not only on a prior endog enous NANC stimuli but also on the parasympathetic drive acting through NO. Therefore, the relaxing action of sildenafil is at least partially mediated by endothelium.

This proposal, in a way, describes why sildenafil treatment improves erectile function in patients with erectile dysfunction secondary to traumatic spinal cord injury, with no difference in patients who did and did not have residual erectile function at baseline (Hultling et al., 1998). Clinical reports about improved erectile function after radical prostatectomy (Lowentritt et al., 1999 \& Zippe et al., 1998) can also be considered within this concept. However, other biochemical substances locally released from the endothelial or smooth muscle components of the erectile tissue may also take part in this function. The premise that NO could modulate corporeal smooth muscle function concerns with its original description as an endothelium-derived relaxing factor, this substance was discovered in vasculature to derive from endothelial cells and to induce vascular smooth muscle relaxation (Palmer et al., 1987). Cholinergic agents, alpha-adre nergic antagonists, endothelium-derived relaxing factor, peptides, prostaglan dins, histamine, calcium channel blocking agents, and other nonspecific vasodilators are some of the substances that induce cavernosal muscle relaxa tion (Anderson, 1993 \& Holmquist et al., 1990).

However, the present study showed that acetylcholine alone when used at high concentrations was a more effective relaxant agent than all other treatment agents including the combination of sodium nitroprusside 
and sildenafil. This contradictory result implies that although acetylcholine releases NO by stimulating muscarinic receptors at lower concentrations, high concentrations of acetylcholine has a direct relaxation effect on isolated rabbit cavernosal smooth muscle. The relaxation effect of acetylcholine at higher concentrations may be mediated by decreasing the intracellular sequest ration, probably by direct reduction of calcium transport by way of voltagedependent calcium channels or sarcop lasmic reticulum not by hyperpola rization or NO. Extensive studies are needed for clarification.

The data of the present study indicate that sildenafil enhances the relaxing effect of both SNP and Ach on phenylephrine-induced contractions of rabbit cavernosal tissue in varying degrees. However, functional organ both studies must be interpreted with caution. Because the cyclic nucleotide turnover rates in isolated tissue prepar ations are low, relatively high concentr ations of phosphodiesterase inhibitors are needed to elevate the cyclic nucleo tide levels and produce a significant tissue response. Additionally, the effects of sildenafil on rabbit corporeal smooth muscle may not be entirely translatable to humans, even though the phosphor diesterase isoenzyme distribution may be similar homogenously.

The present study revealed that SNP-stimulated corpus cavernosal smooth muscle relaxation was impaired in diabetic rabbits compared to age matched controls. This impairment was enhanced in the presence of sildenafil which was observed to enhance SNPstimulated relaxation of corpus caver nosal tissue from age-matched control rabbits. These finding are in accordance with those of Ballard et al. (1996) and Rendell et al. (1999) who showed that sildenafil potentiates NO-mediated corpus cavernosal relaxation of healthy rabbits and reported that sildenafil enhances cGMP formation and accum ulation. Our findings are also in agreement with that of Thompson et al. (2001) and Utkan et al. (2001) who showed that SNP-stimulated cGMP formation was impaired in diabetic rabbit corpus cavernosal tissue and it was improved in the presence of sildenafil. These studies together with our study provide evidence for the possibility of using selective phosp hodiesterase inhibitors in the treatment of diabetic impotance.

Since SNP dissociates in solution to generate $\mathrm{NO}$, which in turn activates guanylyl cyclase, these results suggest that diabetes mellitus impairs the activity of this enzyme causing a reduction in cGMP production. This finding is in contrast, however, to an earlier study that showed that cGMP formation was enhanced in the corpus cavernosum from diabetic rats (Miller $e t$ al., 1994). These differences may be ascribed to species variation and severe catabolic status of the diabetic rats (Thompson and Mikhailidis, 1992). The diabetic rat is not an ideal model to use in the present study, since unlike the diabetic rabbit and man, it has elevated high density lipoprotein levels and is not prone to atheroscelerosis which is also an established risk factor for erectile dysfunction (Virag et al., 1984; Krane et al., 1989; Azadzoi and DeTejada, 1991).

Sildenafil is a selective and potent phosphodiesterase type $\mathrm{V}$ inhibitor that inhibits the hydrolysis of cGMP, thereby elevating levels of this cyclic nucleotide (Jeremy et al., 1997). As sildenafil normalized the reduced SNPmediated relaxations of diabetic corpus cavernosum, we suggest that the actions of this drug can compensate for the diabetes-induced impairement of 
guanylyl cyclase activity and demon strate that type $\mathrm{V}$ phosphodiesterase activity is intact in diabetic corpus cavernosal tissue.

Thompson et al. (2001) found that SNP \& Ach-stimulated cGMP formation was impaired in the diabetic group compared to age-matched controls and observed that this impairment was overcome in the presence of sildenafil. As stimulation by $\mathrm{ACh}$ is dependent on NO release by the activation of endothelial NO-synthase (e NOS) leading to endothelium-dependent NOmediated smooth muscle relaxation, there could also be a defect in eNOS activity in diabetics apart from impaired guanylyl cyclase activity as previously suggested by Sullivan et al. (1998) who also showed that SNP-stimulated cGMP formation was not significantly different between age-matched controls and diabetic corpus cavernosal tissues.

It is now accepted that NANC neurotransmission plays an important, if not a key role in mediating penile erection (Kim et al., 1991; De Tejada, 1992; Trigo-Rocha et al., 1993; Finberg et al., 1993). One of the principal neurotransmitters released by NANC neurons is NO, which causes the formation of cGMP and corpus cavernosal relaxation (Bredt and Snyders, 1994).

In the present study, a significant impairment in electrical field stimulation-mediated corpus cavernosal relaxation after 5 months of diabetes mellitus was found. This result is in line with that of Thompson et al. (2001).

Since electrical field stimulation elicits relaxation through activation of the NANC neurons that innervate the corpus cavernosum, these data suggest that diabetic neuropathy may have developed after 5 months of diabetes mellitus. There is evidence to support this supposition, since early signs of vascular neuropathy characterized by a reduction in the neuronal content and relase of noradrenalin by sympathetic nerves is evident in rabbits 6 weeks after the induction of diabetes mellitus (Cohen et al., 1990). It is therefore conceivable that with time, the biochemical changes could cause some degree of neuropathy. In turn, this could lead to the impairment of this NANC pathway, resulting in erectile dysfun ction. Reduced relaxation to electrical field stimulation in corpus cavernosal tissue taken from diabetic patients with erectile dysfunction has also been reported (Pickard et al., 1994). Interestingly, this was associated with a lack of NO production and not an inherent inability of the corpus cavernosum to relax.

A reduction in NO could result from a defect in NO synthesis and thus NANC neurotransmission or quenching of NO through the production of superoxide radicals and advanced glycosylation end-products (Ceriello et al., 1991; Hoffman et al., 1995). As these factors are thought to play a role in the pathogenesis of diabetic erectile dysfunction. Sildenafil was found to enhance the relaxation of the corpus cavernosum in response to electrical field stimulation in age-matched controls and 5 months diabetic rabbits.

The present findings suggest that despite the early development of diabetic neuropathy, sildenafil still remains effective in eliciting corpus cavernosal smooth muscle relaxation although we can not predict how effective it would be if severe neuropathy is present. In such cases coadministration of a NO-donor may compensate for the impairement of NO bioavailability, not only as a result of impaired NANC neurotransmission but also as a consequence of impaired corpus cavernosal endothelial function 
and diabetes-induced advancedglycosylation end-products or superoxide formation.

\section{References}

1. Anderson, K.E. (1993): Pharmacology of lower urinary tract smooth muscles and penile erectile tissues. Pharmacol. Rev. 45: 253-308.

2. Aydin, S.; Ozbek, H.; Yilmaz, Y.; Atilla, M.K.; Bayrakli, H. and Cetin, H. (2001): Effects of sildenafil citrate, acetylcholine, and sodium nitroprusside on the relaxation of rabbit cavernosal tissue in vitro. Urology 58:119-124.

3. Azadzoi, K.M. and De Tejada, I.S. (1991): Hypercholesterolemia impairs endothelium-dependent relaxation of rabbit corpus cavernosum smooth muscle. J. Urol. 146, 238-240.

4. Azadzoi, K.M. and De Tejada, I.S. (1992): Diabetes mellitus impairs neurogenic and endothelium-dependent relaxation of rabbit corpus cavernosum smooth muscle. J. Urol. 148, 15871591.

5. Azadzoi, K.M. and Goldstein, I. (1992): Erectile dysfunction due to atherorecelerotic vascular disease: the development of an animal model. J. Urol. 147, 1675-1681.

6. Ballard, S.A.; Gingell, C.J. and Tang, K. (1998): Effects of sildenafil on the relaxation of human corpus cavernosum tissue in vitro and on the activities of cyclic nucleotide phosphodiesterase isoenzymes. J. Urol. 159:2164-2171.

7. Ballard, S.A.; Turner, L.A. and Naylor, A.M. (1996): Sildenafil (Viagra), a potent selective inhibitor of type 5 phosphodiesterase enhances nitric oxide-dependent relaxation of rabbit corpus cavernosum. Br. J. Pharmacol. 118, 153p.

8. Beavo, J.L. (1992): Cyclic nucleotide phosphodiesterases: functional implic ations of multiple isoforms. Physiol. Rev. 75:1650-1653.

9. Blanco, R.; De Tejada, I.S.; Goldstein, I., Krane, R.J.; Wotiz, H.H. and Cohen, R.A. (1990): Dysfunctional penile cholinergic nerves in diabetic impotent men. J. Urol. 144, 278-280.

10. Bredt, D.S. and Snyder, S.H. (1994): Nitric oxide: a physiologic messenger molecule. Annu. Rev. Biochem. 63, 175-195.

11. Brown, J.H. and Taylor, P. (1995): Muscarinic receptor agonists and antagonists, in Hardman, JG, Limbird, LE, Molinoff, PB (Eds): Goodman and Gilman's The Pharmacological Basis of Theraputics, $9^{\text {th }}$ ed. New York, McGraw-Hill, pp.141-160.

12. Burnet, A.L. (1995): Role of nitric oxide in the physiology of erection. Biol. Reprod. 52:485-489.

13. Burnet, A.L.; Lowenstein, C.J. and Bredt, D. (1992): Nitric oxide: a physiologic mediator of penile erection. Science 257:401-405.

14. Burnett, A.L. (1997): Nitric oxide in the penis: physiology and pathology. J. Urol. 157: 320-324.

15. Bush, P.A.; Aronson, W.J. and Buga, G.M. (1992): Nitric oxide is a potent relaxant of human and rabbit corpus cavernosum. J. Urol. 147: 1650-1655.

16. Carter, A.J.; Ballard, S.A. and Naylor, A.M. (1998): Effect of the selective phosphodiesterase type 5 inhibitor sildenafil on erectile function in the anesthetized dog. J. Urol. 160:242-246.

17. Ceriello, A.; Giugliano, D.; Quatraro, A.; Dello Russo, P. and Lefebvre, P.V. (1991): Metabolic control may influence the increased superoxide generation in diabetic serum. Diabetes Med. 8, 540-542.

18. Chuang, A.T.; Straus, J.D. and Murphy, R.A. (1988): Sildenafil, a type-5- cGMP phosphodiesterase inhibitor, specially amplifies endoge nous cGMP-dependent relaxation in rabbit corpus cavernosum smooth muscle in vitro. J. Urol. 160:257-261.

19. Cohen, R.A.; Tesfamariam, B.; Weisbord, R.M. and Zitnay, K.M. (1990): Adrenergic denervation in rabbits with diabetes mellitus. Am. J. Physiol. 259, H55-H66.

20. De Tejada, I.S. (1992): Mechanisms for the regulation of penile smooth 
muscle. In: Lue, T.F. (Ed.), World Book of Impotence. Smith/Gordon, London, p.39.

21. De Tejada, I.S.; Goldstein, L.; Azadzoi, K.; Krane, R.J. and Cohen, R.A. (1989): Impaired neurogenic and endothelium-mediated relaxation of penile smooth muscle from diabetic men with impotence. N. Engl. J. Med. 320, 1025-1030.

22. Finberg, J.P.M.; Levy, S. and Vardi, Y. (1993): Inhibition of nerve stimulation-induced vasodilatation in corpus cavernosa of the pithed rat by blockade of nitric oxide synthase. Br. J. Pharmacol. 108, 1038-1042.

23. Hoffman, D.; Seftel, A.D.; Hampel, N. and Resnick, M.I. (1995): Advanced glycation end-products cavernosal nitric oxide. J. Urol. 153, $441 \mathrm{~A}$.

24. Holmquist, F.; Andersson, K.E. and Hedlund, H. (1990): Effects of pinacidil on isolated human corpus cavernosum penis. Acta Physiol. Scand. 138: 463-467.

25. Holmquist, F.; Stief, C.G. and Jonas, U. (1991): Effects of the nitric oxide synthase inhibitor N-nitro-L-arginine on the erectile response to cavernous nerve stimulation in the rabbit. Acta Physiol. Scand. 141: 441-442.

26. Hulting, C.; Giuliano, F.O. and Quirk, F. (1998): Effect of sildenafil on quality of life in men with erectile dysfunction caused by traumatic spinal cord injury. Int. J. Impot. Res. 10:3237.

27. Ignarro, L.J.; Bush, P.A. and Buga, G.M. (1990): Nitric oxide and cGMP formation upon field stimulation cause relaxation of corpus cavernosum smooth muscle. Biochem. Biophys. Res. Commun. 170:843-848.

28. Jeremy, J.Y.; Ballard, S.; Naylor, A.; Miller, M.A.W. and Angelini, G.D. (1997): Effect of sildenafil (viagra), a specific inhibitor of cGMP phosphodiesterase on cAMP and cGMP formation by the rabbit corpus cavernosum in vitro. Br. J. Urol. 79, 958-963.
29. Kim, N.; Azadzoi, K.M.; Goldstein, I. and De Tejada, I.S. (1991): A nitric oxide-like factor mediates nonadrenergic non cholinergic neurogenic relaxation of penile corpus cavernosum smooth muscle. J. Clin. Invest. 88, 112118.

30. Krane, R.J.; Goldstein, I. and De Tajeda, I.S. (1989): Impotence. N. Engl. J. Med. 321, 1648-1659.

31. Lerner, S.E., Melman, A. and Christ, G.J. (1993): A review of erectile dysfunction: new insights and more questions. J. Urol. 149, 1246-1255.

32. Lowentritt, B.H.; Scardino, P.J. and Miles, B.J. (1999): Sildenafil citrate after radical retropubic prostatectomy. J. Urol. 162: 1614-1617.

33. Meyer, M.F.; Jahier, A. and Krah, H. (1993): Intracavernosal application of SIN-I in rabbit and man: functional and toxicological results. Ann. Urol. 27:179-182.

34. Miller, M.A.W.; Morgan, R.J.; Thompson, C.S.; Mikhailidis, D.P. and Jeremy, J.Y. (1994): Adenylate and guanylate cyclase activity in the penis and aorta of the diabetic rat: an in vitro study. Br. J. Urol. 74:106-111.

35. Moreland, R.B.; Goldstein, I. and Traish, A. (1998): Sildenafil, a novel inhibitor of phosphodiesterase type 5-in human corpus cavernosum smooth muscle cells. Life Sci. 62:309-318.

36. Padma-Nathan, H.; Hellstrom, J.G. and Kaiser, F.E. (1997): Treatment of men with erectile dysfunction with transurethral alprostadil. N. England. J. Med. 336: 1-7.

37. Palmer, R.M.; Ferrige, A.G. and Moncada, S. (1987): Nitric oxide release accounts for the biological activity of endothelium derived relaxing factor. Nature 327:524-528.

38. Pickard, R.S.; King, P.; Zar, M.A. and Powell, P.H. (1994): Corpus cavernosal relaxation in impotent men. Br. J. Urol. 74, 485-491.

39. Rendell, M.S.; Rajfer, J., Wicker, P.A. and Smith, M.D. (1999): Sildenafil for treatment of erectile dysfunction in men with diabetes. A 
randomized control trial. JAMA 281, 421-426.

40. Shabsigh, R.; Fishman, I.J.; Schum, C. and Dunn, J.K. (1991): Cigarette smoking and other vascular risk factors in vasculogenic impotence. Urology 38, 227-231.

41. Shenfeld, D.; Hanani, J.; Shalhav, A.; Vardi, Y. and Goldwasser, B. (1995): Papaverine-phentolamine alone for intracorporeal injection therapy: a clinical double-blind study. J. Urol. 154, 1017-1019.

42. Sullivan, M.E.; Thompson, C.S.; Mikhailidis, D.P.; Morgan, R.J.; Angelini, G.D. and Jeremy, J.Y. (1998): Differential alterations of prostacyclin, cyclic AMP and cyclic GMP formation in the corups cavernosum of the diabetic rabbit. Br. J. Urol. 82, 578-584.

43. Thompson, S.S. and Mikhailidis, D.P. (1992): Haematological profile and plasma and urinary biochemistry in experimental models of diabetes mellitus-predictive rabbit. Br. J. Urol. 82:578-584.

44. Thompson, C.S.; Mumtaz, F.H.; Khan, M.A.; Wallis, R.M.; Mikhailidis, D.P.; Morgan, R.J.; Angelini, G.D. and Jeremy, J.Y. (2001): The effect of sildenafil on corpus cavernosal smooth muscle relaxation and cyclic GMP formation in the diabetic rabbit. European Journal Pharmacology 425, 57-64.

45. Trigo-Rocha, F.; Hsu, G.L. and Donattucci, C.F. (1994): Intracellular mechanism of penile erection in monkeys. Neurol. Urodyn. 13:71-80.

46. Trigo-Rocha, F.; Hsu, G.L.; Donatucci, C.F. and Lue, T.F. (1993): The role of cyclic adenosine monophosphate, cyclic guanosine monophosphate, endothelium, and nonadrenergic, noncholinergic, neurot ransmission in canine penile erection. J. Urol. 149, 872-877.

47. Utkan, T.; Yildirim, M.K.; Yildirim, S. and Sarioglu, Y. (2001): Effects of the specific phosphodiesterase inhibitors on alloxan-induced diabetic rabbit cavernous tissue in vitro. Int. J. Impot. Res. 13(1): 24-30.

48. Virag, R. (1982): Intracavernosal injection of papaverine for erectile failure. Lancet 2, 938.

49. Virag, R.; Bouilly, P. and Frydman, D. (1984): Is impotence an arterial disorder? A study of arterial risk factors in 440 impotent men. Lancet 181-184.

50. Von Heyden, B.; Donatucci, C.; Kaula, N. and Lue, T.F. (1993): Intracavernous pharmacology for impotence: selection of appropriate agent and dose. J. Urol. 149, 12881290.

51. Wang, R., Higuera, T.R. and Sikka, S.C. (1993): Penile erections induced by vasoactive intestinal peptide and sodium nitroprusside. Urol. Res. 21:7578.

52. Zippe, C.D.; Kedia, A.W. and Kedia, K. (1998): Treatment of erectile dysfunction after radical prostatectomy with sildenafil citrate. Urology 52: 963966. 


\section{تأثير السيلدينافيل ستريت المثبط النوعي لإنزيم الفوسفوداي إستيريز5

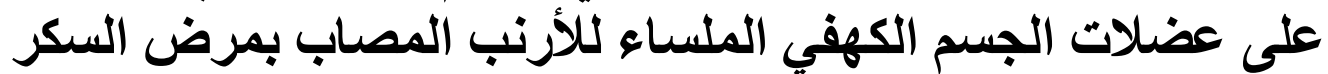

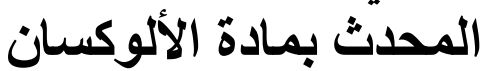

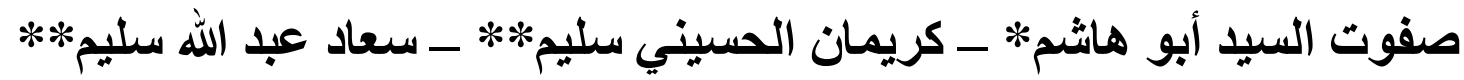

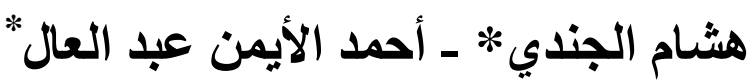

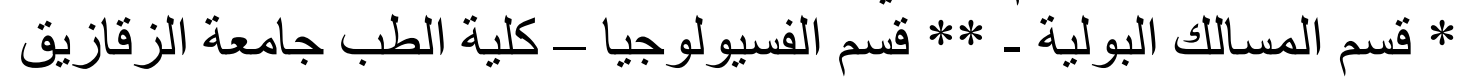
لقد أجريت هذه الدراسة لفحص:

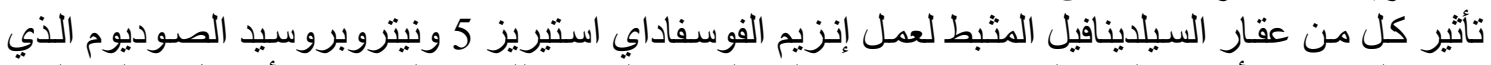

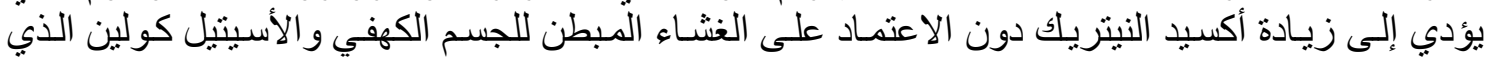

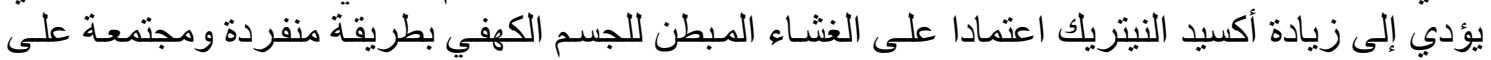

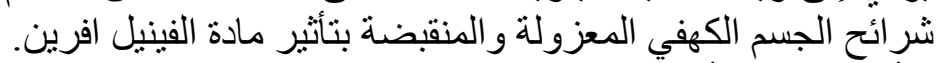

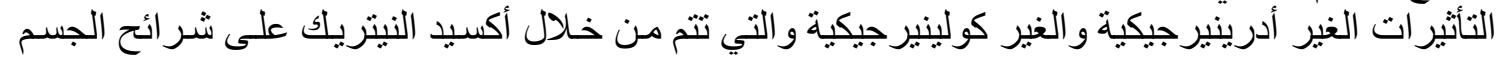

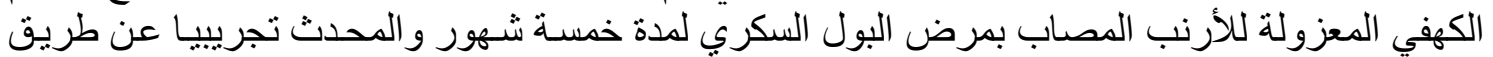

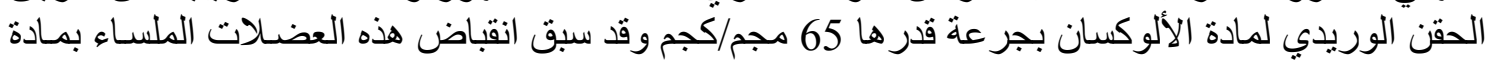
الفينيل إفرين.

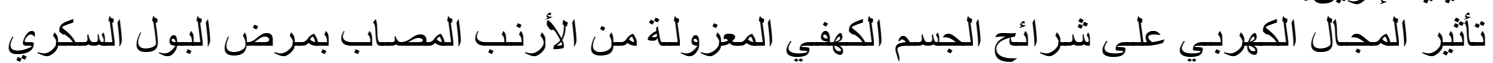

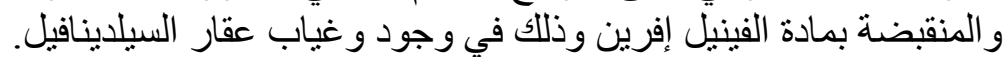

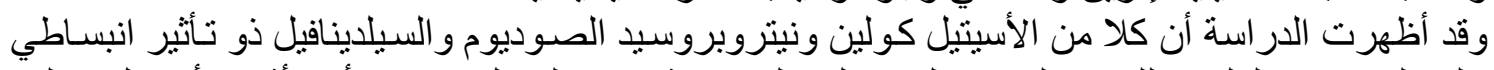

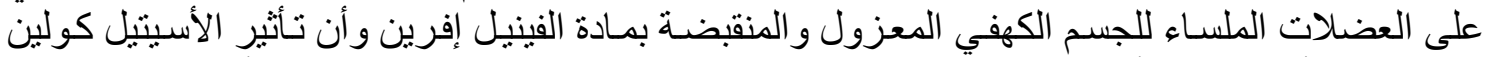

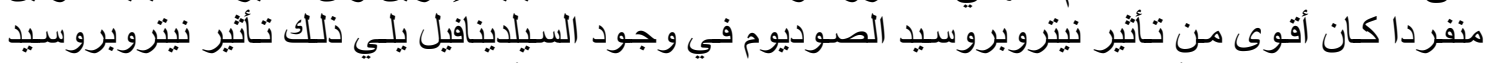

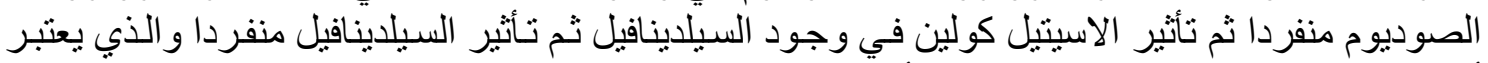

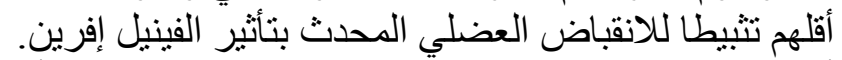

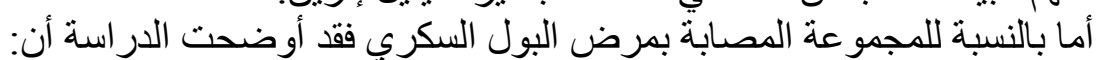

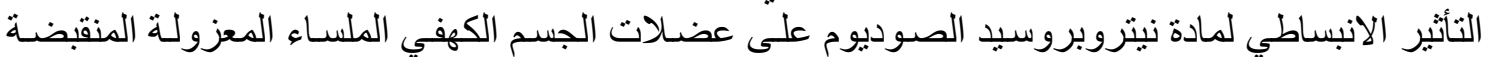

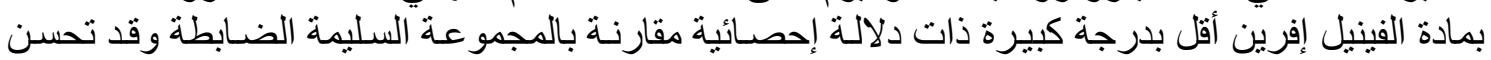

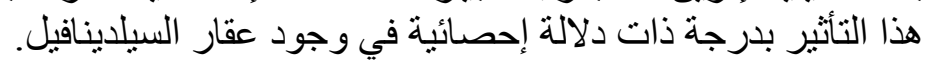

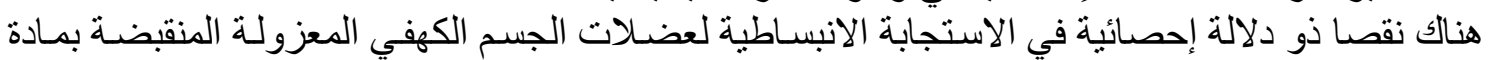

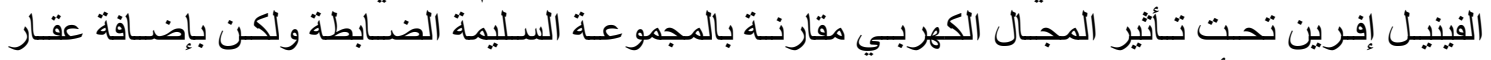

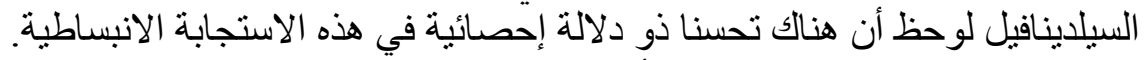

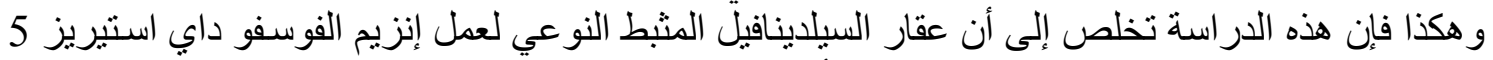

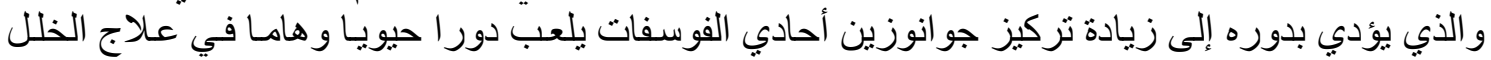

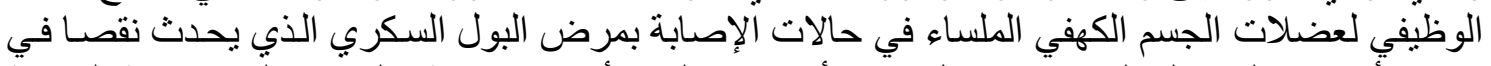

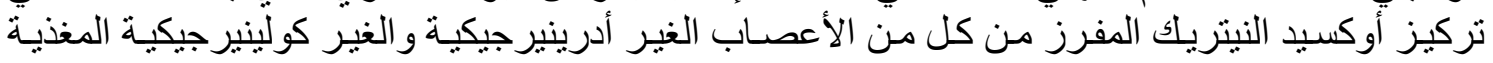
للجسم الكهفي وكذلك من الغشاء المبطن للجسم الكهني. 